\title{
Article \\ Two Design Options for Compact Linear Accelerators for High Flux Neutron Source
}

\author{
Xiaowen Zhu*(D), Claude Marchand (D), Olivier Piquet and Michel Desmons
}

check for

updates

Citation: Zhu, X.; Marchand, C.;

Piquet, O.; Desmons, M. Two Design Options for Compact Linear Accelerators for High Flux Neutron Source. Appl. Sci. 2022, 12, 386. https://doi.org/10.3390/app 12010386

Academic Editors: Jorge

Feuchtwanger, Mario De Cesare and Victor Etxebarria

Received: 1 October 2021

Accepted: 25 December 2021

Published: 31 December 2021

Publisher's Note: MDPI stays neutral with regard to jurisdictional claims in published maps and institutional affiliations.

Copyright: (c) 2021 by the authors Licensee MDPI, Basel, Switzerland. This article is an open access article distributed under the terms and conditions of the Creative Commons Attribution (CC BY) license (https:// creativecommons.org/licenses/by/ $4.0 /)$.
IRFU, CEA, Université Paris-Saclay, F-91191 Gif-sur-Yvette, France; claude.marchand@cea.fr (C.M.); olivier.piquet@cea.fr (O.P.); michel.desmons@cea.fr (M.D.)

* Correspondence: zhuxw13@pku.edu.cn

\begin{abstract}
We describe and compare two optimized design options of RF linear accelerators with different resonant frequencies at $162.5 \mathrm{MHz}\left(\mathrm{f}_{0}\right)$ and $325 \mathrm{MHz}\left(2 \cdot \mathrm{f}_{0}\right)$. The RFQ + DTL linacs have been designed to provide $13 \mathrm{MeV}$ acceleration to a proton beam for achieving a fast neutron yield of not lower than $10^{13} \mathrm{n} / \mathrm{s}$ via ${ }^{9} \mathrm{Be}(\mathrm{p}, \mathrm{n}){ }^{9} \mathrm{~B}$ reaction in pulsed-mode operation. Our design studies show that none of the two options is better than the other, but that the choice of operating frequency will mainly be determined by the accelerator length and RF cost consideration. This study can serve as a basis for the design of an initial stage of a new high brilliance Compact Accelerator-driven Neutron Source (CANS), aiming to use neutron scattering techniques for studying material properties in fundamental physics, materials science, nuclear energy, as well as for industries and societal challenges.
\end{abstract}

Keywords: particle beam transport; RF cavities; power RF sources; medical accelerator technology; accelerators for industry; accelerators for materials science

\section{Introduction}

Compact Accelerator-based Neutron Source (CANS) facilities [1-5] create the possibility of an intense source of neutrons with modest capital cost, more flexible than a dedicated fission reactor or a spallation neutron source [6-10] in terms of management of targets and wastes, accelerator-upgrading, safety constraints, decommissioning, etc. They typically operate in pulsed mode with virtually any desired time structure and thus provide optimum neutron fluxes to the neutron scattering instruments. In addition, to operate in pulse mode can make the heat removal issue in the target easier.

Such an Accelerator-based Neutron Source (ABNS) is composed of an ion source (IS), a low energy beam transport line (LEBT), a radio frequency quadrupole (RFQ) to bunch and pre-accelerate the beam, a medium energy beam transport line (MEBT), an accelerating structure like a drift-tube linac (DTL) for example, a high energy beam transport line (HEBT) and a target system, as shown in Figure 1. In this paper, we only study options using RFQ + DTL linacs as accelerating structures, comparing designs at two different frequencies of $\mathrm{f}_{0}=162.5 \mathrm{MHz}$ and $2 \cdot \mathrm{f}_{0}=325 \mathrm{MHz}$. An example of a new CANS project that may benefit from the studies presented here is the SONATE project, initiates at CEA Paris-Saclay [11].

The main reactions useful for neutron production are $\operatorname{Li}(\mathrm{p}, \mathrm{n}), \operatorname{Be}(\mathrm{p}, \mathrm{n}), \operatorname{Be}(\mathrm{d}, \mathrm{n}), \mathrm{C}(\mathrm{d}$, $n), d(d, n), t(d, n)$, respectively [12]. However, the first three reactions are the most favorable ones.

Usually $(d, n)$ reactions are exothermic. Their drawback is a high Q-value, which leads to a harder neutron spectrum and increases difficulty in the moderator design. Furthermore, they will easily induce activation issues in the accelerator parts and make the maintenance more complicated.

The endothermic ${ }^{7} \mathrm{Li}(\mathrm{p}, \mathrm{n}){ }^{7} \mathrm{Be}$ and ${ }^{9} \mathrm{Be}(\mathrm{p}, \mathrm{n}){ }^{9} \mathrm{~B}$ are more attractive. Compared to $(\mathrm{d}, \mathrm{n})$ reactions, the neutron spectrum is relatively soft, which will benefit moderation. 
However, beryllium and lithium have different properties. Due to the low melting point $(453.65 \mathrm{~K})$ and thermal conductivity $\left(85 \mathrm{~W} \mathrm{~m}^{-1} \mathrm{~K}^{-1}\right)$ and the high-power density deposited in the target material, it can be difficult to keep the lithium target solid, which leads to the selection of liquid lithium (LiLiT) in the target design [13,14]. Moreover, the residual radioactivity of product nucleus, ${ }^{7} \mathrm{Be}$, should be carefully handled in the target system.

In contrast, beryllium is strong, more elastic than steel, does not oxidize in air, and has more favorable thermodynamic properties, which make this material ideal for a watercooled neutron source [15]. Proton reactions at low energy favor lithium from a consideration of neutron yield alone. However, as the proton beam moves to higher energy, the neutron yield from beryllium is superior to lithium.

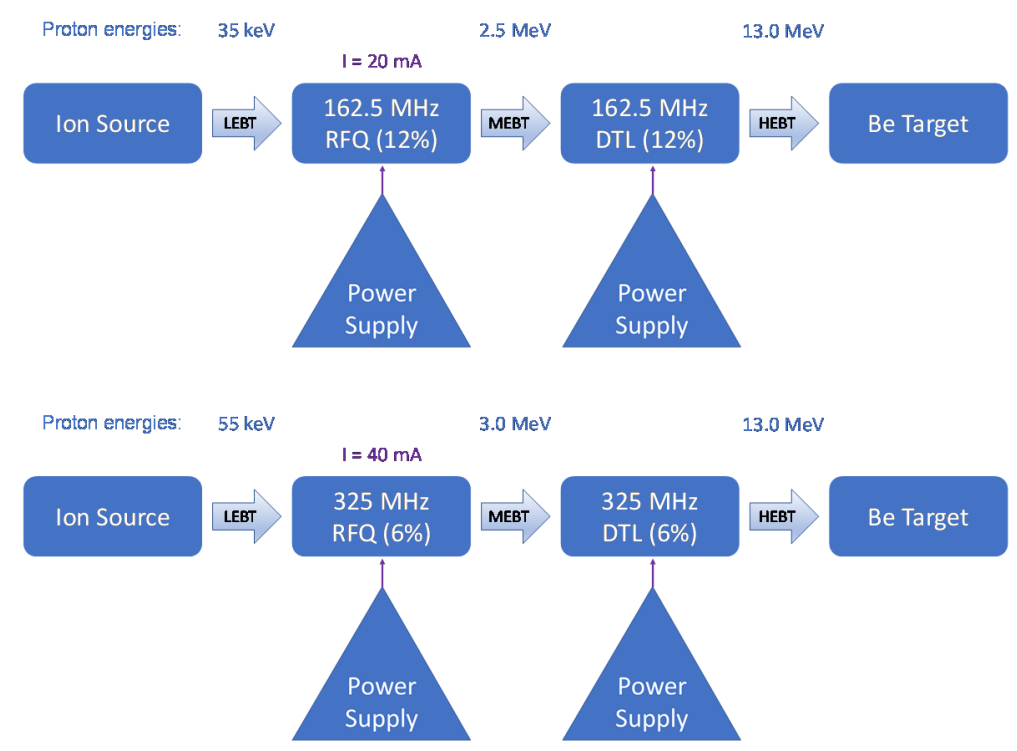

Figure 1. Schematic diagram of the ABNS layout: (Upper) a $162.5 \mathrm{MHz}$ design option, (Lower) a $325 \mathrm{MHz}$ design option.

Considering the requirements of input proton beam current and bombarding energy, the total neutron yields have been collected from the literature for proton energies up to $23 \mathrm{MeV}$. Figure 2 shows the total neutron yield from $\operatorname{Be}(\mathrm{p}, \mathrm{xn})$ across a region of proton energy accessible to the accelerator system [16]. An empirical formula for the total neutron yield, $Y_{N}$, as a function of the proton energy, $E_{p}$ in $\mathrm{MeV}$, is [17],

$$
Y_{N}\left(E_{p}\right)=3.42 \times 10^{8}\left(E_{p}-1.87\right)^{2.05}[\mathrm{n} / \mu \mathrm{C}]
$$

Although the neutron production rate increases monotonically with proton energy, there is a factor of four increase going from $7 \mathrm{MeV}$ to $13 \mathrm{MeV}$. However, a clear drawback of the ${ }^{9} \mathrm{Be}$ target at energies above $13 \mathrm{MeV}$ is the production of ${ }^{7} \mathrm{Be}$ via $(\mathrm{p}, \mathrm{t}),(\mathrm{p}, \mathrm{nd})$ and $(\mathrm{p}$, $2 \mathrm{np}$ ) reactions [18,19]. Threshold energies for these reactions are $13.4 \mathrm{MeV}, 20.4 \mathrm{MeV}$ and $22.8 \mathrm{MeV}$, respectively. The half-life of ${ }^{7} \mathrm{Be}$ is 53 days while it is 12.3 years for tritium.

Since the threshold for the $9 \mathrm{Be}(\mathrm{p}, \mathrm{t}) 7 \mathrm{Be}$ reaction is $13.4 \mathrm{MeV}$, and if we wish to minimize target activation, the maximum proton energy should not exceed $13.4 \mathrm{MeV}$. This choice of maximum proton energy is used in the rest of the paper for the design of the presented accelerating structures for ABNS Linacs. 


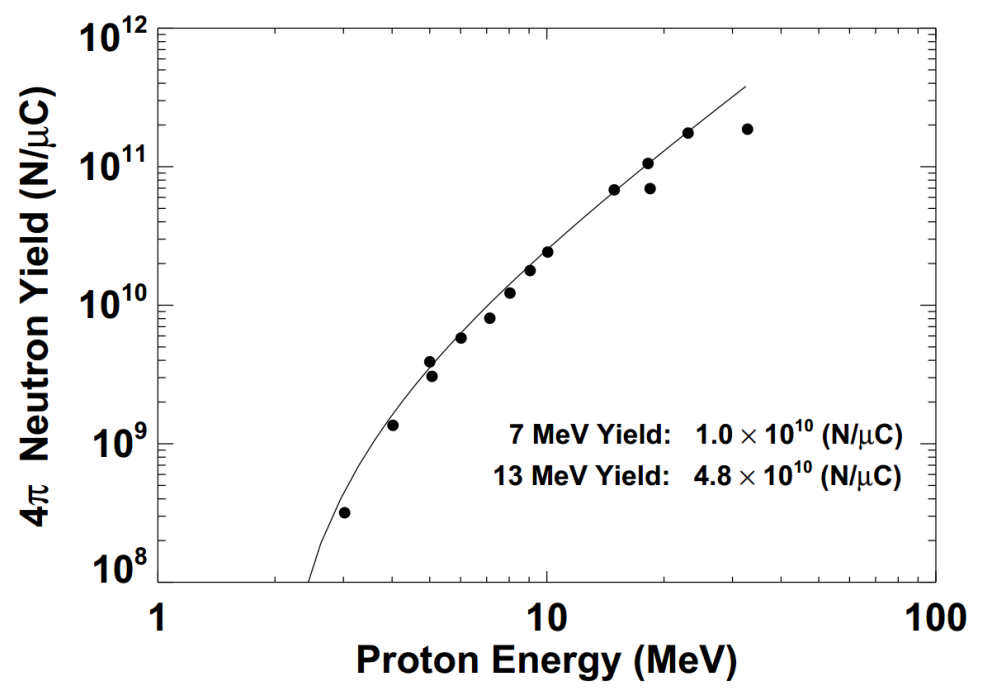

Figure 2. Collected experimental datum on neutron yields from ${ }^{9} \mathrm{Be}(\mathrm{p}, \mathrm{xn})$ reactions and the fitting curve is Equation (1).

\section{Proton RFQ Accelerator Design}

The RFQ accelerator typically outputs a proton beam energy between $2.5 \mathrm{MeV} / \mathrm{u}$ and $3.0 \mathrm{MeV} / \mathrm{u}$ for the injection to an Alvarez DTL linac. A DTL linac cannot accept low velocity particles as there is a minimum injection energy due to the mechanical constraint for accommodation of quadrupole magnets. Examples include J-PARC RFQ-III [20], CERN L4 RFQ [21] and SNS RFQ [22]. All have frequencies ranging from $324 \mathrm{MHz}$ to $402.5 \mathrm{MHz}$ and utilize 4-Vane type RFQ resonator adopting a constant voltage of about $80 \mathrm{kV}$ and having a tank length of $3 \sim 4 \mathrm{~m}$. The advantages of the 4-Vane type RFQ are low dipole field components, high mechanical strength, and easy cooling at high duty cycle operation.

For lower frequency range (150-200 MHz), it is possible to decrease the transition energy (2.5 MeV, for example) to post Alvarez DTL for a longer cell length of $\beta \lambda$ and enable boron neutron capture therapy (BNCT) research using the threshold reaction of 7Li(p,n)7Be [23-26].

\subsection{Design Strategy of RFQ Beam Dynamics}

To start the RFQ beam dynamics designs, we have to determine some key input parameters, for instance, vane voltage, input energy and output energy. For $162.5 \mathrm{MHz}$ and $325 \mathrm{MHz}$ RFQ designs, the main parameters are listed in Table 1.

Table 1. Design parameters of the proton RFQs.

\begin{tabular}{ccc}
\hline Parameters & 162.5 MHz RFQ & 325 MHz RFQ \\
\hline Beam species & $\mathrm{H}^{+}$ & $\mathrm{H}^{+}$ \\
Injection energy $(\mathrm{keV} / \mathrm{u})$ & 35 & 55 \\
Output energy $(\mathrm{MeV} / \mathrm{u})$ & 2.5 & 3.0 \\
Resonant frequency $(\mathrm{MHz})$ & 162.5 & 325 \\
Peak beam current $(\mathrm{mA})$ & 20 & 40 \\
Inter-vane voltage $(\mathrm{kV})$ & 65 & 85 \\
Cavity length $(\mathrm{m})$ & 5.18 & 3.66 \\
Averaged aperture radius $r_{0}(\mathrm{~mm})$ & 5.664 & 3.575 \\
Vane-tip radius $r_{t}(\mathrm{~mm})$ & 4.250 & 2.680 \\
Ratio $\rho_{t}=r_{0} / r_{t}$ & 0.75 & 0.75 \\
Maximum surface field $(\mathrm{MV} / \mathrm{m})$ & $16.85(1.24 \mathrm{Kilpatrick})$ & $32.53(1.82 \mathrm{Kilpatrick})$ \\
Input $\varepsilon_{t}$ (norm. rms.) $(\mathrm{mm} \cdot \mathrm{mrad})$ & 0.200 & 0.200 \\
Output $\varepsilon_{t}$ (norm. rms.) $(\mathrm{mm} \cdot \mathrm{mrad})$ & 0.249 & 0.206 \\
Output $\varepsilon_{l}$ (norm. rms.) $(\mathrm{mm} \cdot \mathrm{mrad})$ & 0.360 & 0.296 \\
Transmission $(\%)$ & 99.6 & 98.2 \\
\hline
\end{tabular}




\subsubsection{Vane Voltage and Kilpatrick Limit}

In general, a higher vane voltage will result in a shorter RFQ length. However, a higher voltage will increase the risk of RF breakdown during operation and result in a larger cavity power consumption. Therefore, we use two different strategies for these two RFQs and make a comparison of both designs, namely low voltage $(65 \mathrm{kV})$, low Kilpatrick limit $\left(K_{p}=1.24\right)$ design for $162.5 \mathrm{MHz}$ RFQ and high voltage $(85 \mathrm{kV})$, high Kilpatrick limit $\left(K_{p}=1.82\right)$ design for $325 \mathrm{MHz}$ RFQ.

For normal conducting cavities, the Kilpatrick criterion for sparking as a function of frequency $(\mathrm{MHz})$ is defined as following [27]:

$$
f(\mathrm{MHz})=1.64 E^{2} e^{-\frac{8.5}{E}}
$$

where $E$ in $\mathrm{MV} / \mathrm{m}$ is the Kilpatrick electric field. At frequencies of $162.5 \mathrm{MHz}$ and $325 \mathrm{MHz}$, the Kilpatrick electric fields are calculated to be $13.595 \mathrm{MV} / \mathrm{m}$ and $17.846 \mathrm{MV} / \mathrm{m}$, respectively. For the highest stability, the peak surface electric field on the vane-tips is usually held below the 1.85 Kilpatrick limit.

The averaged accelerating gradient $(\mathrm{MeV} / \mathrm{u} / \mathrm{m})$ and Kilpatrick limit of various proton RFQs all over the world is summarized in Figure 3 [28-37]. Thanks to cranking up the peak surface electric field to 1.82 Kilpatrick at the higher frequency of $325 \mathrm{MHz}$, a shorter RFQ can accelerate a proton beam to desired output energy. Though the $162.5 \mathrm{MHz}$ RFQ has a longer cavity length, it has a lower Kilpatrick factor of 1.24 and thus less risk of electric breakdown and has more potential for future BNCT research. After comparing with the design parameters of other proton RFQs, both designs are considered to be reliable for high duty factor operations.

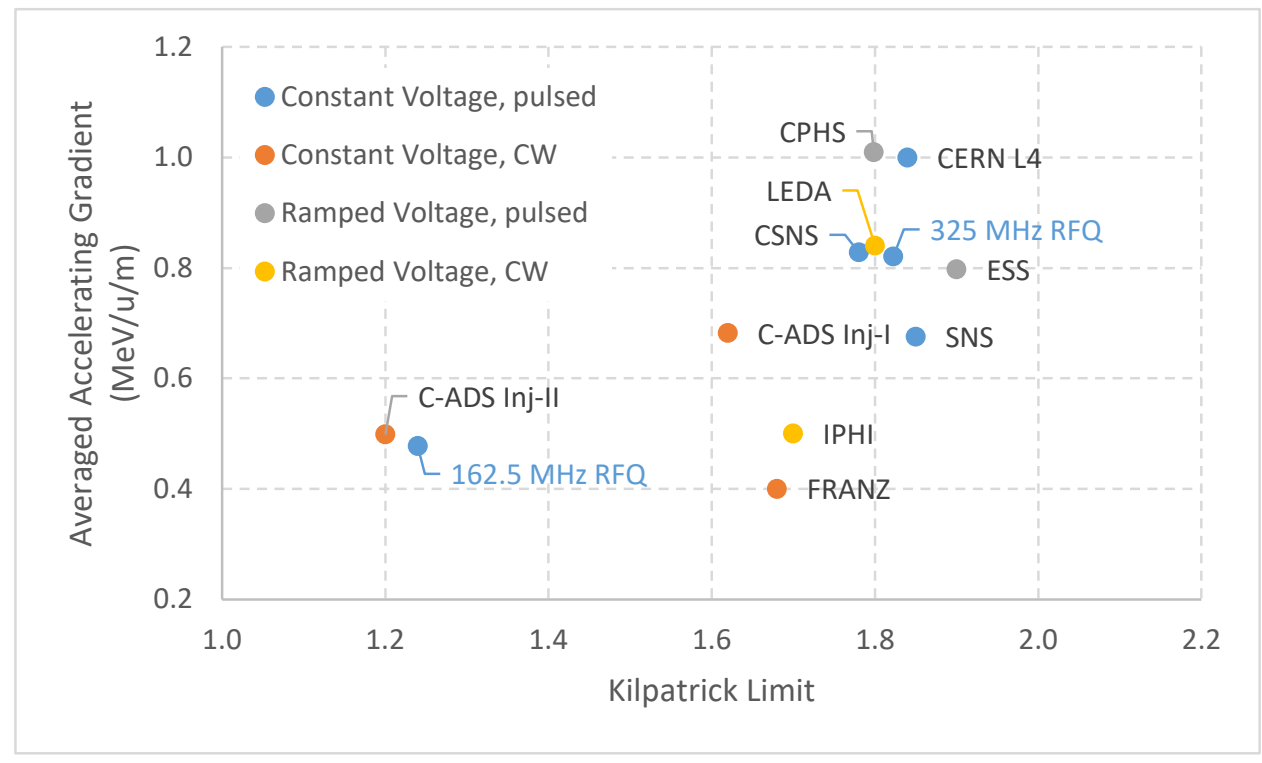

Figure 3. Energy gain per nucleon and Kilpatrick limit of various proton RFQs in the world.

\subsubsection{Injection Energy}

The injection energy has a main influence on the space charge effect, which is described by generalized perveance $K$ [38]. It's a dimensionless parameter, defined by

$$
K=\frac{q I}{2 \pi \varepsilon_{0} m_{0} c^{3} \beta^{3} \gamma^{3}}
$$

where $q$ is the ion charge, $I$ is the beam current, $\varepsilon_{0}$ is the input emittance, $c$ is the speed of light, $\beta$ is the normalized speed and $\gamma$ is the Lorentz factor. According to Equation (3), the space charge effect of the $35 \mathrm{keV} / \mathrm{u}, 20 \mathrm{~mA}$ proton beam in the $162.5 \mathrm{MHz}$ RFQ design is 
equivalent to that of the $55 \mathrm{keV} / \mathrm{u}, 40 \mathrm{~mA}$ proton beam in the $325 \mathrm{MHz}$ RFQ. In addition, keeping a modest extraction voltage will help to decrease the risk of ion source sparking and is beneficial to its long-term operation.

\subsubsection{Output Energy}

The RFQ output energy or transition energy to the post Alvarez DTL is primarily determined by the mechanical length of a permanent magnet quadrupole (PMQ). The typical mechanical lengths of PMQs used in the $402.5 \mathrm{MHz}$ SNS DTL [39] and $352.2 \mathrm{MHz}$ CERN L4 DTL [40] are $35 \mathrm{~mm}$ and $40 \mathrm{~mm}$, and the corresponding cell lengths $(\beta \lambda)$ in the first cells are around $54 \mathrm{~mm}$ and $68 \mathrm{~mm}$. Thus, for a $325 \mathrm{MHz}$ DTL design with the first cell length of around $73 \mathrm{~mm}$, the RFQ output energy should be no less than $3.0 \mathrm{MeV}$, for decreasing the difficulty of housing a PMQ. In contrast, for a $162.5 \mathrm{MHz}$ DTL, the first cell length will be about $147 \mathrm{~mm}$ at an output energy of $3 \mathrm{MeV}$. There is no doubt that a PMQ can be easily housed inside the first drift tube. However, to choose a lower output energy of $2.5 \mathrm{MeV}$ will leave open the possibility for BNCT research with a single RFQ accelerator-based neutron source via the proton-lithium reaction.

\subsection{Beam Dynamics Simulations}

In the beam dynamics designs, the proton RFQs are optimized with the utilization of the ParmteqM code [41]. The main design parameters of the proton RFQs (162.5 MHz vs. $325 \mathrm{MHz}$ ) with constant inter-vane voltages of $65 \mathrm{kV}$ and $85 \mathrm{kV}$ are shown in the Figure 4.

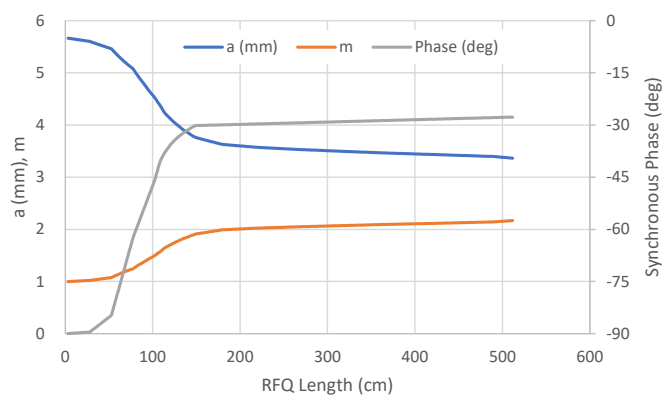

(a)

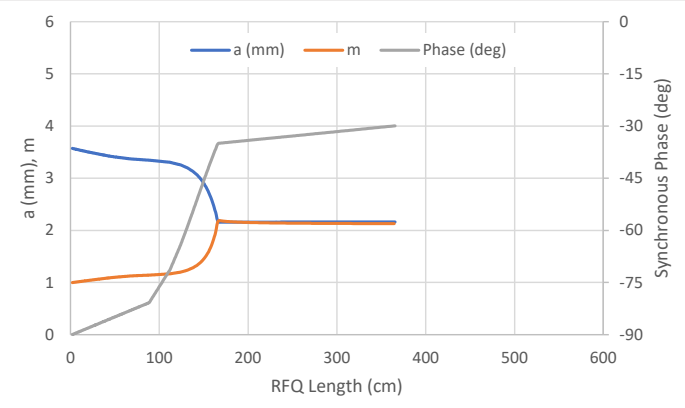

(b)

Figure 4. Evolutions of the synchronous phase (Phase in degree), aperture radius (a in $\mathrm{mm}$ ) and modulation factor (dimensionless m) along RFQs: (a) $162.5 \mathrm{MHz}$ design, (b) $325 \mathrm{MHz}$ design.

Both RFQs hold a Kilpatrick limit lower than 1.85 and a high energy gain per unit length. The cavity lengths are $5.18 \mathrm{~m}$ and $3.66 \mathrm{~m}$, with synchronous phases of $-90.0^{\circ} \sim-27.7^{\circ}$ and $-90.0^{\circ} \sim-30.0^{\circ}$, respectively. For $162.5 \mathrm{MHz}$ RFQ design, the minimum aperture radius is $3.37 \mathrm{~mm}$ and the maximum modulation factor $\mathrm{m}$ is 2.17 . Correspondingly, they are $2.16 \mathrm{~mm}$ and a factor of 2.16 in the $325 \mathrm{MHz}$ RFQ design.

The multi-particle tracking simulations are carried out by using the ParmteqM code with an input distribution of 100,000 macro-particles. The transverse phase spaces $\left(x-x^{\prime}\right)$ and $\left(y-y^{\prime}\right)$ are $4 D$ waterbag, while the longitudinal one $(\varphi-W)$ is uniform. The transmission efficiency and transverse RMS envelopes as a function of the longitudinal position of the RFQ accelerators are given in Figure $5 \mathrm{a}-\mathrm{d}$. Besides, the transverse particle distributions $\left(x-x^{\prime}\right)$ at RFQ inputs of both designs (162.5 MHz vs. $325 \mathrm{MHz}$ ) are shown in Figure 5e,f. Both RFQs have a high transmission efficiency over $95 \%$. The beam losses mainly concentrate on the sections of the shaper and gentle buncher in the RFQ accelerators. The averaged RMS beam size at the $162.5 \mathrm{MHz}$ RFQ exit is $0.84 \mathrm{~mm}$, while the $325 \mathrm{MHz}$ RFQ has a smaller one of $0.61 \mathrm{~mm}$ at the output. 


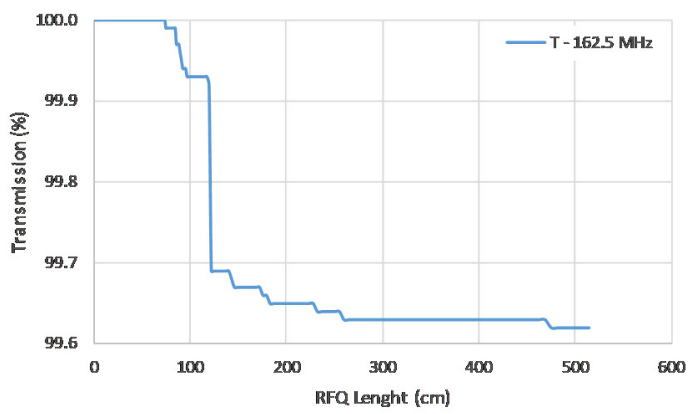

(a)

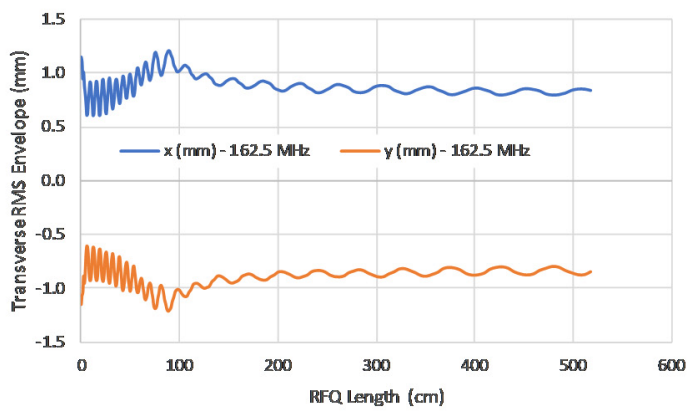

(c)

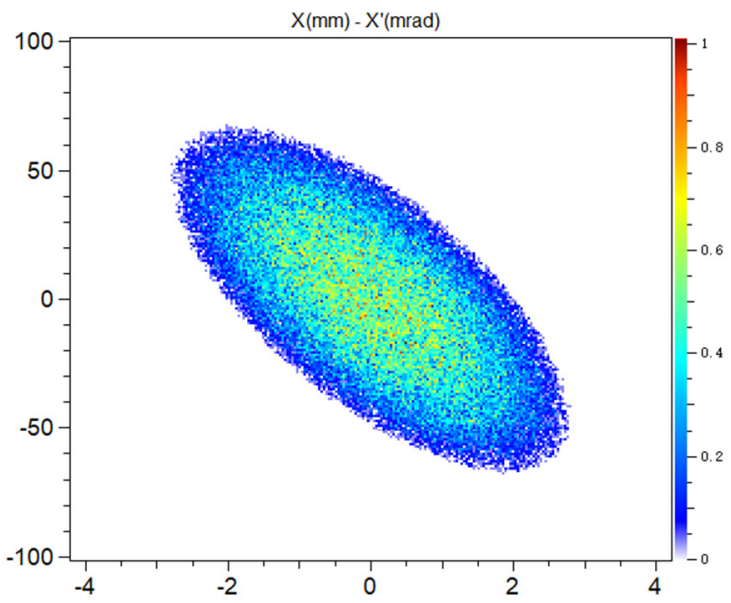

(e)

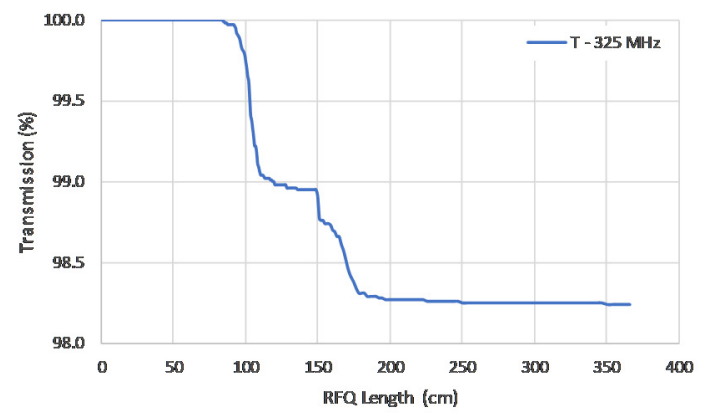

(b)

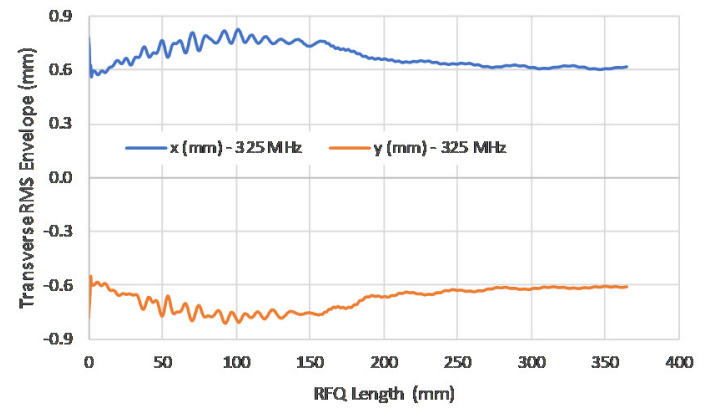

(d)

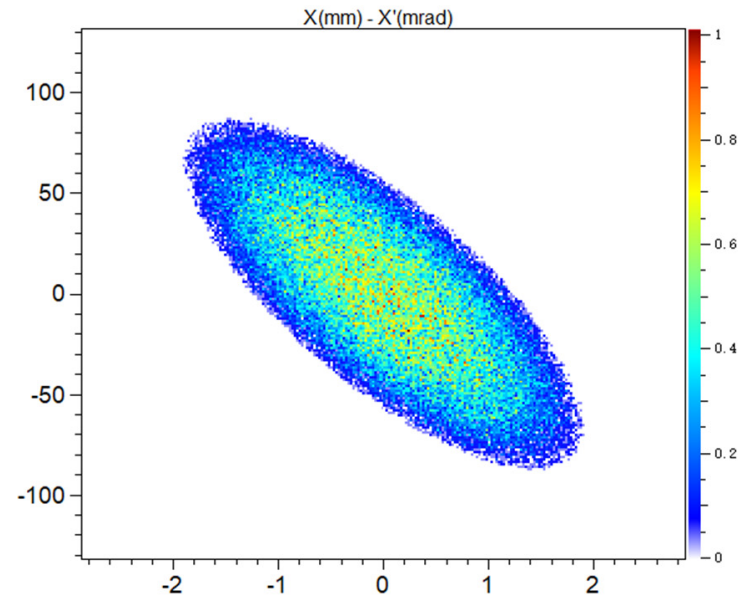

(f)

Figure 5. Simulated beam transmission efficiencies, transverse RMS envelopes and input transverse particle distributions $\left(\mathrm{x}-\mathbf{x}^{\prime}\right)$ of beam dynamics in the $162.5 \mathrm{MHz}(\mathbf{a}, \mathbf{c}, \mathbf{e})$ and $325 \mathrm{MHz}(\mathbf{b}, \mathbf{d}, \mathbf{f})$ RFQs.

\subsection{RF Design Studies}

The 2-dimentional cavities, as shown in Figure 6, are designed to satisfy the requirements of the RFQ physics designs and to understand the cavity properties and to estimate the power loss in the cavity, using the CST MWS code [42]. The cross-section, average aperture radius and vane-tip radius of both RFQs are kept constant along the full cavity length for an easy tuning and the possibility of applying a shaper-cutter in the machining. The adoption of a square profile in the $162.5 \mathrm{MHz}$ will benefit from easier openings of holes for tuners, power couplers, vacuum port and so on in the mechanical processing. However, if a similar square profile is used at the frequency of $325 \mathrm{MHz}$, that will limit the available spaces for tuners and couplers. Thus, an octagonal profile is more favorable to a $325 \mathrm{MHz}$ RFQ. 


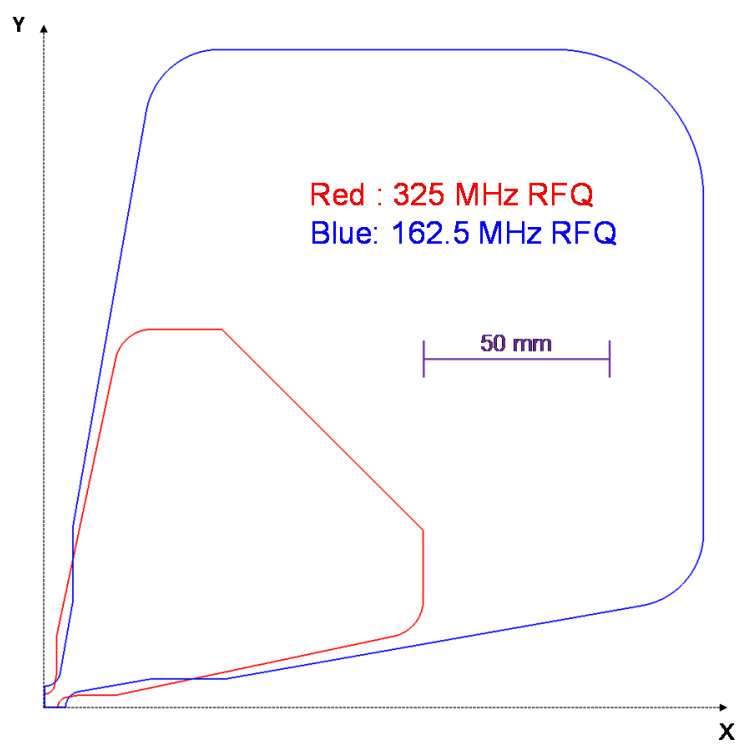

Figure 6. Simulated cross-section profiles in both RFQs: the square shape in blue represents the 162.5 MHz RFQ design, while the octagonal shape in red shows the $325 \mathrm{MHz}$ RFQ design; $X$ and $Y$ are in the units of $\mathrm{mm}$, and the transverse dimension of $325 \mathrm{MHz}$ RFQ is about $60 \%$ of that of the 162.5 MHz RFQ.

To have a better understanding of cavity performances in both designs, a comparison of high-frequency parameters between the square $162.5 \mathrm{MHz}$ RFQ and the octagonal $325 \mathrm{MHz}$ RFQ is presented in Table 2. The half-width of the $325 \mathrm{MHz}$ RFQ inner wall is $101.66 \mathrm{~mm}$, which is about $60 \%$ of that in $162.5 \mathrm{MHz}$ RFQ, leaving a slope width of $76.6 \mathrm{~mm}$, which is adequate for tuners and couplers. The mode spacings between the fundamental quadrupole mode $\left(\mathrm{Q}_{0}\right)$ and dipole mode $\left(\mathrm{D}_{0}\right)$ are $5.0 \mathrm{MHz}$ and $10.6 \mathrm{MHz}$, respectively, which should guarantee sufficient RF stability during operation. Besides, the square $162.5 \mathrm{MHz}$ RFQ has a larger unloaded quality factor because of its higher area to perimeter ratio. Furthermore, the corresponding specific shunt impedance is about 2.7 times higher, reaching up to $272.1 \mathrm{k} \Omega \cdot \mathrm{m}$. Taking account of a factor of 1.3 for power loss scaling to 3-dimentional cavity, the estimated total power in the $162.5 \mathrm{MHz}$ RFQ is evaluated to be one-third of that in the $325 \mathrm{MHz}$ RFQ.

Table 2. Result comparison of 2-dimensional RFQ electrical parameters.

\begin{tabular}{ccc}
\hline Parameters & 162.5 MHz RFQ & 325 MHz RFQ \\
\hline Quadrupole frequency $\mathrm{Q}_{0}(\mathrm{MHz})$ & 162.5 & 325 \\
Half-width of RFQ inner wall $(\mathrm{mm})$ & 176.90 & 101.66 \\
Dipole mode frequency $\mathrm{D}_{0}(\mathrm{MHz})$ & 157.5 & 314.4 \\
Vane voltage $(\mathrm{kV})$ & 65 & 85 \\
Quality factor (unloaded) & 16,836 & 11,855 \\
Profile area to perimeter ratio $(\mathrm{mm})$ & 41.2 & 20.6 \\
Specific shunt impedance $(\mathrm{k} \Omega \cdot \mathrm{m})$ & 272.1 & 101.8 \\
Power loss per unit length $(\mathrm{kW} / \mathrm{m})$ & 15.5 & 71.0 \\
Beam power $(\mathrm{kW})$ & 50 & 120 \\
Estimated cavity power $(\mathrm{kW})$ & 104.4 & 337.8 \\
Estimated total power $(\mathrm{kW})$ & 154.4 & 457.8 \\
Max magnetic field $(\mathrm{A} / \mathrm{m})$ & 2148.1 & 5268.3 \\
\hline
\end{tabular}

\section{Physical Design of DTL Accelerator}

The post Alvarez DTL will accelerate the incoming proton beam of RFQ output energy of 2.5 3.0 MeV up to $13 \mathrm{MeV}$. The TM010 mode is the operating mode in the DTL tank and the phase shift from cell to cell is 0-degree (or 360-degree). Based on the proven 
design experiences of SNS DTL [37] and CERN L4 DTL [43], the Permanent Magnet Quadrupoles (PMQs) are chosen to be the DTL focusing elements, which yields a smaller drift tube diameter and higher shunt impedance compared to those drift tubes equipped with electromagnets. Another advantage of the adoption of PMQs is that there is no need for the current supply wires or power converters.

\subsection{Design Philosophy and Constraints}

The first design priority is to provide an acceleration to the proton beam up to $13 \mathrm{MeV}$. Later we try to make a compact DTL linac design. There is less stringent requirement on the peak RF power.

Other constrains on the design are:

(1) Limiting the peak surface electric field on the drift tubes not exceeding 1.6 times the Kilpatrick limit.

(2) Application of a ramping average E0 field for an easier capture of the proton beam and shortening the tank length to $9.0 \mathrm{~m}$ for the $162.5 \mathrm{MHz}$ DTL design. While for the design of $325 \mathrm{MHz}$ DTL, a constant E0 design is applied to maximize the energy acceptance to the proton beam.

\subsection{Drift Tube Designs}

A series of computations has been carried out using the SUPERFISH code [44] to design drift tubes in the $162.5 \mathrm{MHz}$ and $325 \mathrm{MHz}$ DTLs. The cell length is equal to $\beta \lambda$, where $\lambda$ is the RF wavelength, and they are $1.845 \mathrm{~m}$ for $162.5 \mathrm{MHz}$ and $0.922 \mathrm{~m}$ for $325 \mathrm{MHz}$, respectively. Their corresponding normalized speeds $\left(\beta_{\text {in }}\right)$ at DTL entrances are 0.0732 and 0.0800 .

The tank $(D)$ and drift tube $(d)$ diameters in a DTL have to satisfy the requirement of $\lambda / 4$ post-coupler criteria, which is defined as following [45]:

$$
1.03 \geq \frac{[(D-d) / 2]}{(\lambda / 4)} \geq 0.90
$$

where $\lambda$ presents the RF wavelength. Both diameters also are constrained to make the cavity resonate at the desired frequency. For these purposes, the tank $(D)$ and drift tube $(d)$ diameters of a conventionally post-coupled DTL operating at $162.5 \mathrm{MHz}$ are determined as $(D=102 \mathrm{~cm}, d=15 \mathrm{~cm})$. Similarly, in the $325 \mathrm{MHz} D T L$, they are chosen as $(D=56 \mathrm{~cm}$, $d=9 \mathrm{~cm})$. The frequency in each cell is slightly adjusted by changing some of the other geometrical parameters like the drift tube face angle $(\alpha)$ and gap-to-cell-length ratio $(g / \beta \lambda)$ (see Figure 7).

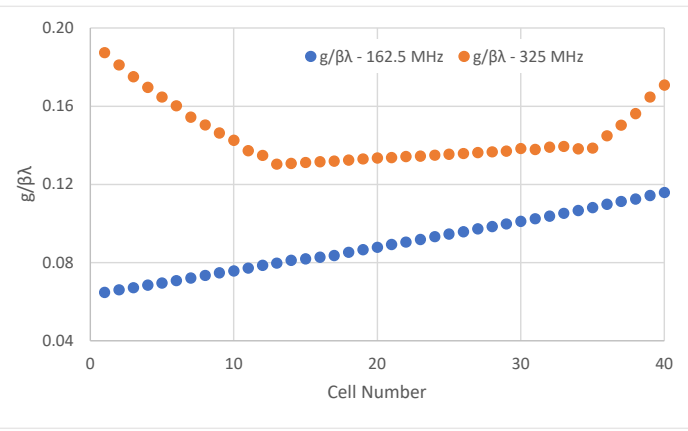

(a)

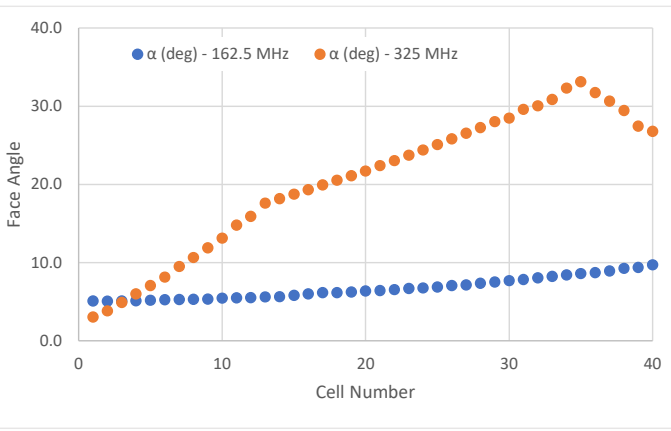

(b)

Figure 7. Gap-to-cell-length ratio (a) and face angle (b) variations as a function of cell number required to achieve the designed resonant frequencies (162.5 MHz design in blue and $325 \mathrm{MHz}$ design in yellow). 


\subsection{Longitudinal Beam Dynamics Considerations}

The designed accelerating gradient E0 is shown in Figure 8a. A ramped average E0 field ranging from $1.10 \mathrm{MV} / \mathrm{m}$ to $1.75 \mathrm{MV} / \mathrm{m}$ is adopted to more easily accept the incoming proton beam and to make the $162.5 \mathrm{MHz}$ DTL length compact. The high average electric accelerating field in the $325 \mathrm{MHz}$ DTL tank is held constant at E0 $=2.85 \mathrm{MV} / \mathrm{m}$, maximizing the energy acceptance and energy gain.

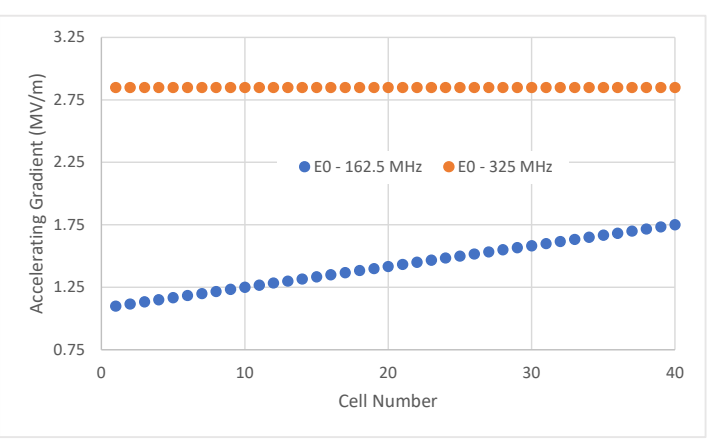

(a)

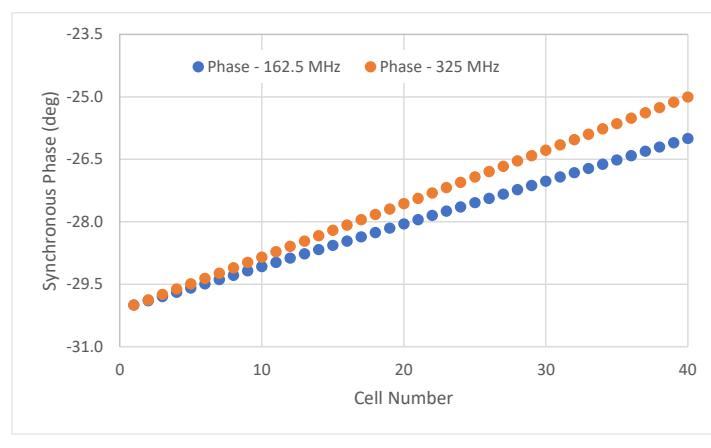

(b)

Figure 8. Accelerating gradients (a) and synchronous phases (b) of both DTL tanks.

The synchronous phases $\left(\varphi_{\mathrm{s}}\right)$, shown in the Figure $8 \mathrm{~b}$, are ramped in both DTLs from $-30^{\circ}$ to $-26^{\circ}$ and from $-30^{\circ}$ to $-25^{\circ}$. The initial synchronous phase starts at the same value of $-30^{\circ}$ at the RFQ exit to capture the proton beam in longitudinal phase space, then ramping $\varphi_{\mathrm{s}}$ to increase the accelerating efficiency.

The longitudinal beam dynamics simulated with the TraceWin code [46] are shown in Figure 9. All macro particles are within the stable bunch widths in the whole DTLs, and no beam loss is found in the longitudinal phase space.

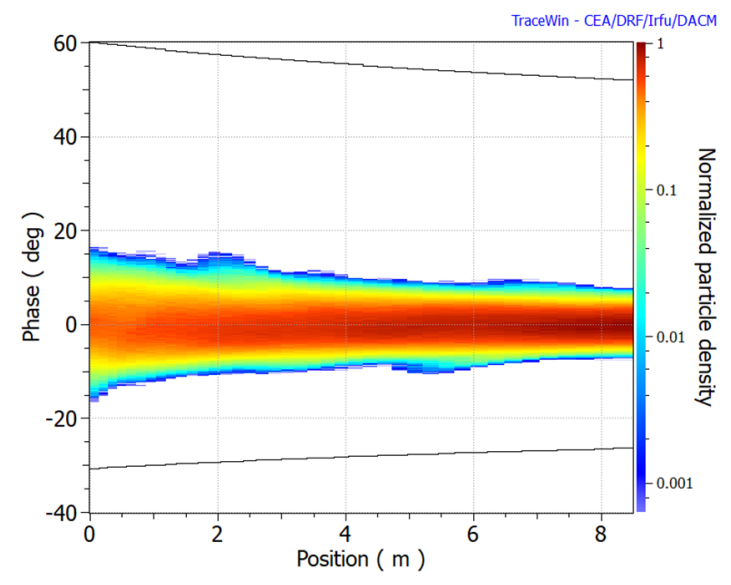

(a)

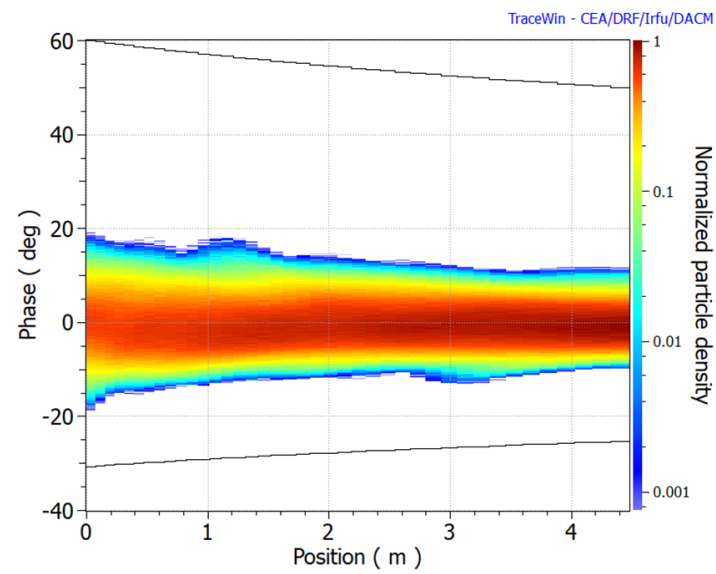

(b)

Figure 9. Simulated longitudinal beam envelopes inside the DTL cavities: (a) $162.5 \mathrm{MHz}$ design, (b) $325 \mathrm{MHz}$ design.

\subsection{Transverse Beam Dynamics Considerations}

The transverse focusing scheme in the DTL transverse beam dynamics is selected to be a FODO lattice, which has merits in requiring a smaller number of PMQs and imposing a less stringent requirement on magnetic gradients.

However, for very high intense beams, the strong space charge effect could yield an equipartitioning process, which will lead to emittance growth and increase the risk of beam losses in the downstream parts of the DTL tanks; therefore, the equipartitioning design 
method is introduced. The quadrupole gradients of FODO lattices are selected to comply with the following design guidelines [38,47]:

(1) $\sigma_{0 \mathrm{t}}<90^{\circ} /$ period;

(2) $\sigma_{0 \mathrm{t}} \neq \mathrm{n} \sigma_{01} / 2$ for $\mathrm{n}=1,3, \ldots$;

(3) Equipartitioning ratio $\approx 1.0$ at full current;

(4) Avoid known parametric resonances;

The PMQ lengths within one DTL tank are fixed, which are $80 \mathrm{~mm}(162.5 \mathrm{MHz}$ design) and $40 \mathrm{~mm}$ (325 MHz design), respectively. Figure 10 shows the required quadrupole gradients to satisfy these constrains for the FODO lattices in both DTLs. The highest quadrupole gradient in the $162.5 \mathrm{MHz}$ design is about $1 / 3$ to that of the $325 \mathrm{MHz}$ DTL design.

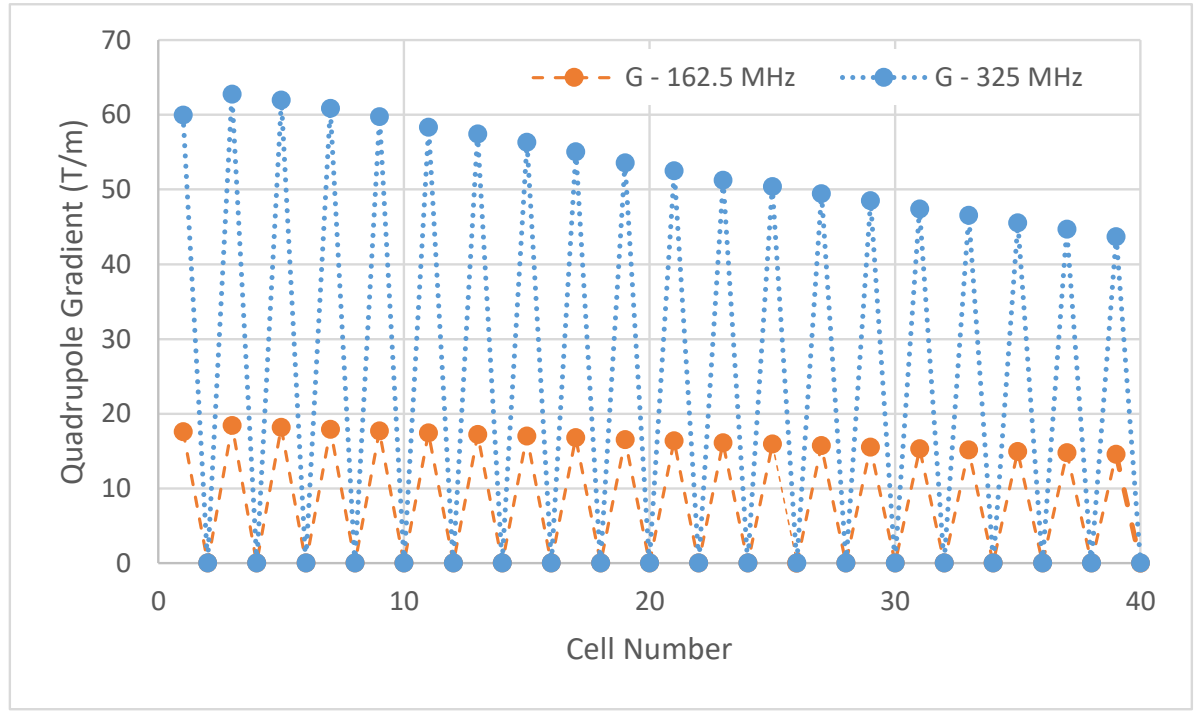

Figure 10. Quadrupole gradients of PMQs inside DTL tanks: $162.5 \mathrm{MHz}$ design in yellow and $325 \mathrm{MHz}$ design in blue.

The beam envelopes along the DTL tanks with FODO lattices are shown in Figure 11. Compared to the $325 \mathrm{MHz}$ design, the transverse beam envelopes in the $162.5 \mathrm{MHz}$ DTL tank have a larger beam size. It should be noted that the beam sizes are all within the aperture radii of drift tubes. As shown in Figure 12, the transverse and longitudinal emittance growths for both designs are within $10 \%$, which presents a low risk of beam losses.

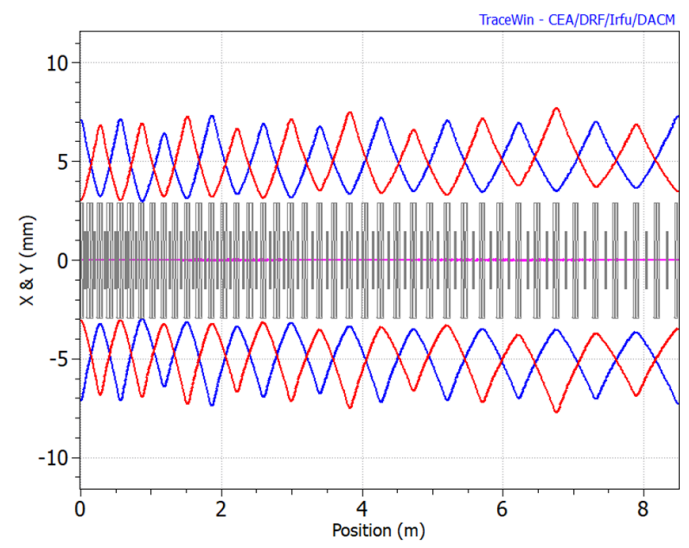

(a)

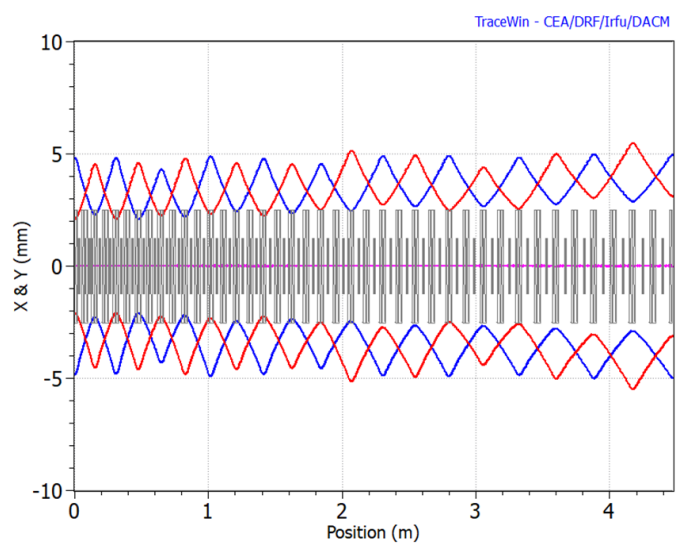

(b)

Figure 11. Transverse beam $3 *$ RMS envelopes ( $X$ in blue and $Y$ in red) along both DTL linacs: (a) $162.5 \mathrm{MHz}$ design, (b) $325 \mathrm{MHz}$ design. 


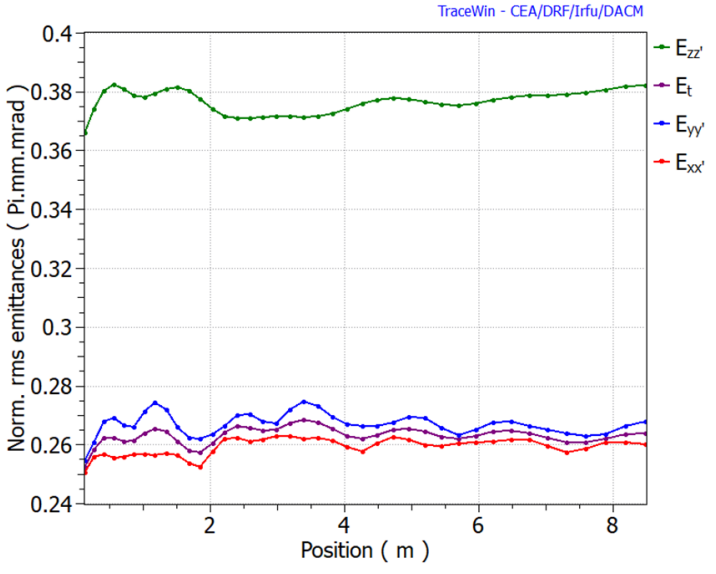

(a)

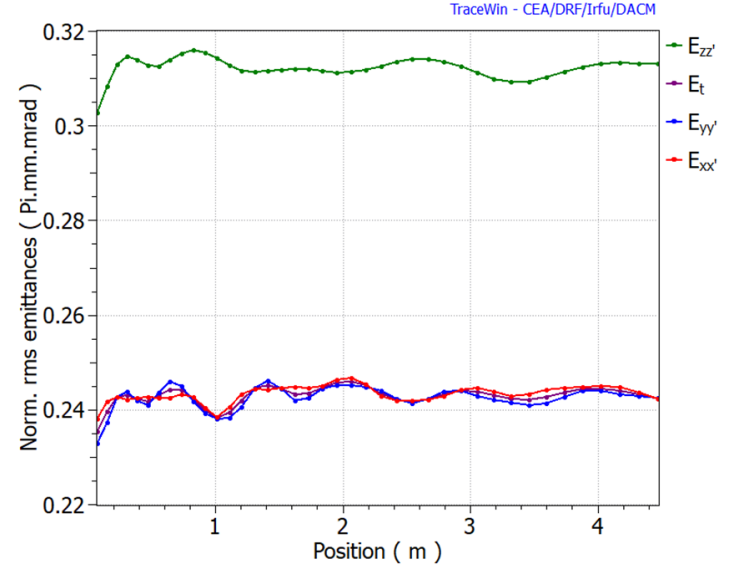

(b)

Figure 12. Emittance growths along both DTL linacs: (a) $162.5 \mathrm{MHz}$ design, (b) $325 \mathrm{MHz}$ design.

\subsection{DTL Cavity Studies}

The DTL cavity studies are performed with the SUPERFISH code to calculate the electromagnetic fields and to estimate the required RF consumption. Each DTL tank consists of a cylindrical cavity and 39 drift tubes mounted on the top side of the cavity with a stem diameter of $2.8 \mathrm{~cm}$. The resonant frequency of each tank is tuned to $162.5 \mathrm{MHz}$ and $325 \mathrm{MHz}$, respectively. Figure 13 shows the on-axis electric-field profiles of the operating mode in both designs and Table 3 summarizes the simulated electromagnetic parameters (for an electrical conductivity of $\sigma=5.8 \times 10^{7} \mathrm{~S} / \mathrm{m}$ ) of DTL tanks.

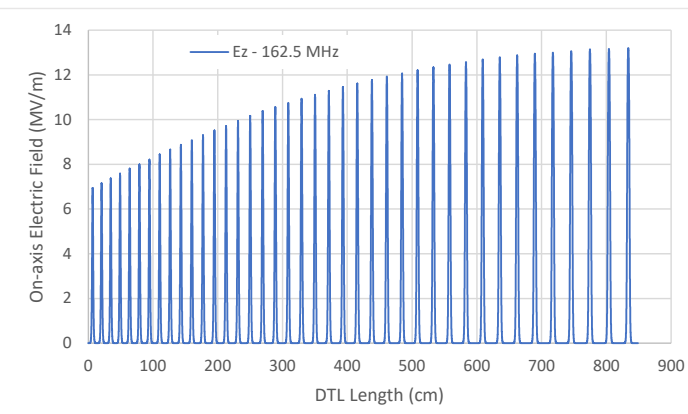

(a)

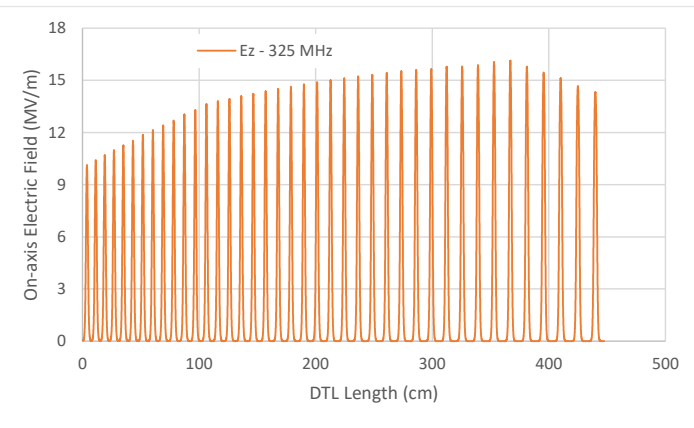

(b)

Figure 13. Ez-field distributions calculated by the SUPERFISH code (a) $162.5 \mathrm{MHz}$ design, (b) $325 \mathrm{MHz}$ design.

Table 3. General DTL parameters.

\begin{tabular}{ccc}
\hline Parameters & $\mathbf{1 6 2 . 5} \mathbf{~ M H z ~ D T L}$ & 325 MHz DTL \\
\hline Operating frequency (MHz) & 162.5 & 325 \\
Input energy (MeV) & 2.5 & 3.0 \\
Output energy (MeV) & 13.0 & 13.0 \\
Peak current (mA) & $20 \mathrm{~mA}$ & $40 \mathrm{~mA}$ \\
Accelerating gradient (MV /m) & $1.10 \rightarrow 1.75$ & 2.85 \\
Synchronous phase (degree) & $-30^{\circ} \rightarrow-26^{\circ}$ & $-30^{\circ} \rightarrow-25^{\circ}$ \\
Kilpatrick limit & 1.6 & 1.6 \\
Tank length (m) & 8.49 & 4.47 \\
Tank diameter $(\mathrm{cm})$ & 102 & 56 \\
\hline
\end{tabular}


Table 3. Cont.

\begin{tabular}{ccc}
\hline Parameters & 162.5 MHz DTL & 325 MHz DTL \\
\hline Drift tube diameter $(\mathrm{cm})$ & 15 & 9 \\
Bore radius $(\mathrm{cm})$ & 1.2 & 1.0 \\
Focusing lattice & FODO & FODO \\
PMQ Length $(\mathrm{mm})$ & 80 & 40 \\
Quadrupole gradient $(\mathrm{T} / \mathrm{m})$ & $18.4 \rightarrow 14.6$ & $62.8 \rightarrow 43.7$ \\
Cell number & 40 & 40 \\
Copper power $(\mathrm{kW})$ & 380.3 & 520.3 \\
Beam power $(\mathrm{kW})$ & 210 & 400 \\
Averaged ZT $(\mathrm{M} \Omega / \mathrm{m})$ & 44.4 & 55.5 \\
Quality factor & 65598 & 53102 \\
Estimated total power $(\mathrm{kW})$ & 590.3 & 920.3 \\
Transmission $(\%)$ & 100 & 100 \\
\hline
\end{tabular}

\section{RF Systems}

The RF system is one of the key components in the accelerator system. Figure 14 gives a summary of the power and frequency reach of the various pulsed/CW RF sources [48]. At the frequencies of $\mathrm{f}_{0}=162.5 \mathrm{MHz}$ and $2 \cdot \mathrm{f}_{0}=325 \mathrm{MHz}$, the RF amplifiers that can possibly drive the RFQ and DTL tanks are based on tetrodes, klystrons and solid-state amplifiers. For tetrode-based amplifier, two Thales tetrodes TH781 [49-53] and TH628 [49,54] can serve this purpose. Specially, the new generation Diacrode (TH628) presents a unique ability in either doubling the output power at a given operating frequency or doubling the frequency at a given power output. When the operation frequency is above $300 \mathrm{MHz}$, klystrons $[49,55,56]$ are common solutions. However, the drawbacks are the high voltage (HV) needs with oil tank for breakdown protection, expensive modulator, and gain curve saturation at full output power. Another option as RF source for accelerators is to use RF solid-state amplifiers, which is becoming more and more popular in recent years. Solid-state amplifiers promise a relatively cost-effective power conversion from DC to RF. The modularization and standardization of a solid-state system allows relatively easy maintenance and inexpensive restoration. In contrast to a conventional tree combiner, the cavity combiner can combine the output power of all single units in one stage, therefore significantly decreasing the fabrication cost and making the RF source compact [57-59].

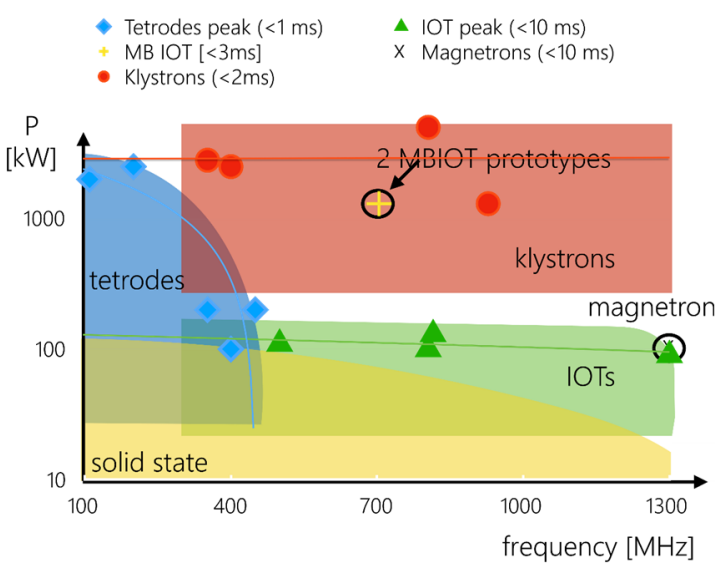

(a)

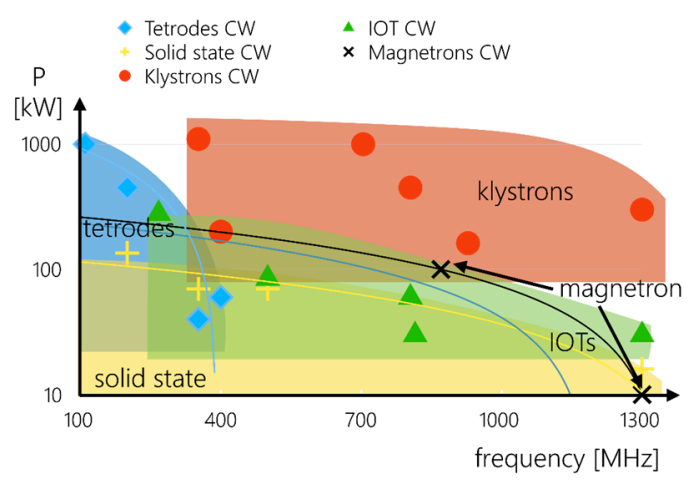

(b)

Figure 14. Power and frequency of various RF sources for pulsed (a) and CW (b) operations up to $1.3 \mathrm{GHz}$. 


\section{Conclusions and Future Research}

Two design options of compact linear accelerator systems at the frequencies of $\mathrm{f}_{0}=162.5 \mathrm{MHz}$ and $2 \cdot \mathrm{f}_{0}=325 \mathrm{MHz}$ are studied. Both designs will provide acceleration of a proton beam up to $13 \mathrm{MeV}$, which then bombards a beryllium target for intense neutron flux generation. The $325 \mathrm{MHz}$ design option would have accelerator sections (RFQ and DTL) of $8.1 \mathrm{~m}$ and a total RF power consumption of $1.4 \mathrm{MW}$. Though the $162.5 \mathrm{MHz}$ design has a longer length of $13.7 \mathrm{~m}$, the total power is only $750 \mathrm{~kW}$, which is one-half of the $325 \mathrm{MHz}$ design requirement. Meanwhile, the overall system efficiencies of both designs are all around $35 \%$. The tolerance analysis of the accelerator physics design and the considerations for RF supply cost, operation cost and total capital costs will be performed in a forthcoming paper.

Author Contributions: Conceptualization, X.Z.; methodology, X.Z.; software, X.Z.; validation, X.Z., O.P. and M.D.; formal analysis, X.Z.; investigation, X.Z.; resources, C.M., O.P. and M.D.; data curation, X.Z.; writing—original draft preparation, X.Z.; writing—review and editing, C.M., O.P. and M.D.; visualization, X.Z.; supervision, O.P. and M.D.; project administration, C.M.; funding acquisition, C.M. All authors have read and agreed to the published version of the manuscript.

Funding: This research received no external funding.

Institutional Review Board Statement: Not applicable.

Informed Consent Statement: Not applicable.

Data Availability Statement: Not applicable.

Acknowledgments: The primary author, Xiaowen Zhu, would like to thank James Stovall for his helpful discussions and suggestions.

Conflicts of Interest: The authors declare no conflict of interest.

\section{References}

1. Anderson, I.; Andreani, C.; Carpenter, J.; Festa, G.; Gorini, G.; Loong, C.-K.; Senesi, R. Research Opportunities with Compact Accelerator-driven Neutron Sources. Phys. Rep. 2016, 654, 1-58. [CrossRef]

2. Baxter, D.V.; Cameron, J.M.; Derenchuk, V.P.; Lavelle, C.M.; Leuschner, M.B.; Lone, M.A.; Meyer, H.O.; Rinckel, T.; Snow, W.M. Status of the Low Energy Neutron Source at Indiana University. Nucl. Instrum. Methods Phys. Res. Sect. B Beam Interact. Mater. At. 2005, 241, 209-212. [CrossRef]

3. Kobayashi, T.; Ikeda, S.; Otake, Y.; Ikeda, Y.; Hayashizaki, N. Completion of a New Accelerator-driven Compact Neutron Source Prototype RANS-II for On-site Use. Nucl. Instrum. Methods Phys. Res. Sect. A Accel. Spectrom. Detect. Assoc. Equip. 2021, 994, 165091. [CrossRef]

4. Zakalek, P.; Cronert, T.; Baggemann, J.; Doege, P.-E.; Rimmler, M.; Voigt, J.; Mauerhofer, E.; Rücker, U.; Gutberlet, T.; Podlech, H.; et al. High-Brilliance Neutron Source Project. J. Phys. Conf. Ser. 2020, 1401, 012010. [CrossRef]

5. Wei, J.; Chen, H.B.; Huang, W.H.; Tang, C.X.; Xing, Q.Z.; Loong, C.K.; Fu, S.N.; Tao, J.Z.; Guan, X.L.; Shimizu, H.M. Compact Pulsed Hadron Source-A University-based Accelerator Platform for Multidisciplinary Neutron and Proton Applications. In Proceedings of the PAC09, Vancouver, BC, Canada, 4-8 May 2009; pp. 1360-1362.

6. SNS. Available online: https://neutrons.ornl.gov/sns (accessed on 1 August 2021).

7. ISIS. Available online: https://www.isis.stfc.ac.uk/ (accessed on 1 August 2021).

8. ESS. Available online: https:/ / europeanspallationsource.se/ (accessed on 1 August 2021).

9. J-PARC. Available online: http://j-parc.jp/c/en/ (accessed on 1 August 2021).

10. CSNS. Available online: http:/ / english.ihep.cas.cn/csns/ (accessed on 1 August 2021).

11. Marchix, A.; Letourneau, A.; Tran, H.N.; Chauvin, N.; Menelle, A.; Ott, F.; Schwindling, J. Saclay Compact Accelerator-driven Neutron Sources (SCANS). J. Phys. Conf. Ser. 2018, 1046, 012009. [CrossRef]

12. Taskaev, S.Y. Accelerator Based Epithermal Neutron Source. Phys. Part. Nucl. 2015, 46, 956-990. [CrossRef]

13. Halfon, S.; Paul, M.; Arenshtam, A.; Berkovits, D.; Bisyakoev, M.; Eliyahu, I.; Feinberg, G.; Hazenshprung, N.; Kijel, D.; Nagler, A.; et al. High-power Liquid-lithium Target Prototype for Accelerator-based Boron Neutron Capture Therapy. Appl. Radiat. Isot. 2011, 69, 1654-1656. [CrossRef]

14. Kobayashi, T.; Miura, K.; Hayashizaki, N.; Aritomi, M. Development of Liquid-lithium Film Jet-flow for the Target of ${ }^{7} \mathrm{Li}(\mathrm{p}, \mathrm{n})^{7} \mathrm{Be}$ Reactions for BNCT. Appl. Radiat. Isot. 2014, 88, 198-202. [CrossRef]

15. CRC Handbook of Chemistry and Physics; CRC Press: Cleveland, OH, USA, 1984; Volume 65. 
16. Lavelle, C.M. The Neutronic Design and Performance of the Indiana University Cyclotron Facility (IUCF) Low Energy Neutron Source (LENS). Ph.D. Thesis, Indiana University, Bloomington, IN, USA, 2010.

17. Lavelle, C.; Baxter, D.; Bogdanov, A.; Derenchuk, V.; Kaiser, H.; Leuschner, M.; Lone, M.; Lozowski, W.; Nann, H.; Przewoski, B.; et al. Neutronic Design and Measured Performance of the Low Energy Neutron Source (LENS) Target Moderator Reflector Assembly. Nucl. Instrum. Methods Phys. Res. Sect. A Accel. Spectrom. Detect. Assoc. Equip. 2008, 587, 324-341. [CrossRef]

18. T-2 Nuclear Information Service. Available online: http://t2.lanl.gov/ (accessed on 1 August 2021).

19. Leuschner, M.; Baxter, D.V.; Kaiser, H.; Lavelle, C.M.; Lozowski, W.R.; Remmes, N.B.; Rinckel, T.; Snow, M.W.; Sokol, P.E. LENS: A New Low Energy Source Design for Research and Education; Indiana University: Bloomington, IN, USA; Available online: www.indiana.edu/ \{\}lens/attachments/publications/LENS-ACNS06.pdf (accessed on 1 August 2021).

20. Kondo, Y.; Hasegawa, K.; Morishita, T.; Jameson, R.A. Beam Dynamics Design of a New Radio Frequency Quadrupole for Beam-current Upgrade of the Japan Proton Accelerator Research Complex Linac. Phys. Rev. Spec. Top. -Accel. Beams 2012, 15, 080101. [CrossRef]

21. Rossi, C.; Arnaudon, L.; Baudrenghien, P.; Bellodi, G.; Brunner, O.; Hansen, J.; Lallement, J.B.; Lombardi, A.M.; Noirjean, J.; Desmons, M.; et al. Commissioning and Operational Experience Gained with the Linac4 RFQ at CERN. In Proceedings of the LINAC2014, Geneva, Switzerland, 31 August-5 September 2014; pp. 926-928.

22. Ratti, A.; Fong, C.; Fong, M.; MacGill, R.; Gough, R.; Staples, J.; Hoff, M.; Keller, R.; Virostek, S.; Yourd, R. Conceptual Design of the SNS RFQ. In Proceedings of the LINAC98, Chicago, IL, USA, 23-28 August 1998; pp. 276-278.

23. Horiike, H.; Murata, I.; Iida, T.; Yoshihashi, S.; Hoashi, E.; Kato, I.; Hashimoto, N.; Kuri, S.; Oshiro, S. Liquid Li Based Neutron Source for BNCT and Science Application. Appl. Radiat. Isot. 2015, 106, 92-94. [CrossRef]

24. Kondo, Y.; Tamura, J.; Yee-Rendon, B. Reference Design of the RFQ for JAEA ADS Linac. In Proceedings of the 3rd J-PARC Symposium (J-PARC2019), Tsukuba, Japan, 23-26 September 2019; p. 011015.

25. Zhu, X.; Wang, H.; Lu, Y.; Wang, Z.; Zhu, K.; Zou, Y.; Guo, Z. 2.5 MeV CW 4-vane RFQ Accelerator Design for BNCT Applications. Nucl. Instrum. Methods Phys. Res. Sect. A Accel. Spectrom. Detect. Assoc. Equip. 2018, 883, 57-74. [CrossRef]

26. Lu, L.; He, T.; Ma, W.; Shi, L.; Yang, L.; Xing, C.; Xu, X.; Sun, L. Research on an Accelerator-based BNCT Facility. In Proceedings of the IPAC2018, Vancouver, BC, Canada, 29 April-4 May 2018; pp. 1024-1027.

27. Kilpatrick, W.D. Criterion for Vacuum Sparking Designed to Include Both rf and dc. Rev. Sci. Instrum. 1957, $28,824-826$. [CrossRef]

28. Ratti, A.; DiGennaro, R.; Gough, R.A.; Hoff, M.; Keller, R.; Kennedy, K.; MacGill, R.; Staples, J.; Virostek, S.; Yourd, R. The Design of a High Current, High Duty Factor RFQ for the SNS. In Proceedings of the EPAC 2000, Vienna, Austria, 26-30 June 2000; pp. 495-497.

29. Rossi, C.; Bourquin, P.; Lallement, J.B.; Lombardi, A.M.; Mathot, S.; Timmins, M.; Vandoni, G.; Vretenar, M.; Cazaux, S.; Delferriere, O.; et al. The Radiofrequency Quadrupole Accelerator for the Linac4. In Proceedings of the LINAC08, Victoria, BC, Canada, 29 September-3 October 2008; pp. 157-159.

30. Fu, S.; Fang, S.; Wei, J. China Spallation Neutron Source Linac Design. In Proceedings of the LINAC 2006, Knoxville, TN, USA, 20-25 August 2006; pp. 222-226.

31. Li, Z.; Cheng, P.; Geng, H.; Guo, Z.; He, Y.; Meng, C.; Ouyang, H.; Pei, S.; Sun, B.; Sun, J.; et al. Physics Design of an Accelerator for an Accelerator-driven Subcritical System. Phys. Rev. Spec. Top.-Accel. Beams 2013, 16, 080101. [CrossRef]

32. Li, C.; Zhang, Z.; Qi, X.; Xu, X.; He, Y.; Yang, L. Beam Dynamics Study of RFQ for CADS with a 3D Space-charge-effect. Chin. Phys. C 2014, 38, 037005. [CrossRef]

33. Zhang, C.; Schempp, A. Beam Dynamics Studies on a $200 \mathrm{~mA}$ Proton Radio Frequency Quadrupole Accelerator. Nucl. Instrum. Methods Phys. Res. Sect. A Accel. Spectrom. Detect. Assoc. Equip. 2008, 586, 153-159. [CrossRef]

34. Xing, Q.Z.; Cai, J.C.; Bai, Y.J.; Cheng, C.; Du, T.B.; Guan, X.L.; Wei, J.; Xiong, Z.F.; Zhang, H.Y.; Zheng, S.X.; et al. Design of the CPHS RFQ Linac at Tsinghua University. In Proceedings of the IPAC'10, Kyoto, Japan, 23-28 May 2010; pp. $792-794$.

35. Eshraqi, M.; Danared, H.; De Prisco, R.; Jansson, A.; Levinsen, Y.; Lindroos, M.; Miyamoto, R.; Muñoz, M.; Ponton, A. ESS Linac Beam Physics Design Update. In Proceedings of the IPAC2016, Busan, Korea, 8-13 May 2016; pp. 947-950.

36. Young, L.M.; Rybarcyk, L.J.; Schneider, J.D.; Schulze, M.E.; Smith, H.V. High Power Operations of LEDA. arXiv 2000, arXiv:physics/0008158.

37. Ferdinand, R.; Beauvais, P.Y.; Duperrier, R.; France, A.; Gaiffier, J.; Lagniel, J.M.; Painchault, M.; Simoens, F.; Balleyguier, P. Status Report on the $5 \mathrm{MeV}$ IPHI RFQ. arXiv 2000, arXiv:physics/0008145.

38. Reiser, M. Theory and Design of Charged Particle Beams; John Wiley \& Sons: Hoboken, NJ, USA, 2008.

39. Henderson, S.; Abraham, W.; Aleksandrov, A.; Allen, C.; Alonso, J.; Anderson, D.; Arenius, D.; Arthur, T.; Assadi, S.; Ayers, J.; et al. The Spallation Neutron Source Accelerator System Design. Nucl. Instrum. Methods Phys. Res. Sect. A: Accel. Spectrom. Detect. Assoc. Equip. 2014, 763, 610-673. [CrossRef]

40. Ramberger, S.; Alharbi, N.; Bourquin, P.; Cuvet, Y.; Gerigk, F.; Lombardi, A.M.; Sargsyan, E.; Vretenar, M.; Pisent, A. Drift Tube Linac Design and Prototyping for the CERN Linac4. In Proceedings of the LINAC08, Victoria, BC, Canada, 29 September-3 October 2008; pp. 184-186.

41. Crandall, K.R.; Wangler, T.P.; Young, L.M.; Billen, J.H.; Neuschaefer, G.H.; Schrage, D.L. RFQ Design Codes; LA-UR-96-1836; Los. Alamos National Laboratory: Los Alamos, NM, USA, 2005.

42. CST. Available online: www.cst.com (accessed on 1 August 2021). 
43. Buzio, M.; Golluccio, G.; Lombardi, A.; Mateo, F. Magnetic Qualification of Permanent Magnet Quadrupoles for CERN's Linac4. IEEE Trans. Appl. Supercond. 2012, 22, 4004304. [CrossRef]

44. Billen, J.H. Poisson Superfish; LA-UR-96-1834; Los. Alamos National Laboratory: Los Alamos, NM, USA, 1996.

45. Chao, A.W.; Mess, K.H. (Eds.) Handbook of Accelerator Physics and Engineering; World scientific: Singapore, 2013.

46. Uriot, D.; Pichoff, N. Status of TraceWin code. In Proceedings of the IPAC'15, Richmond, VA, USA, 3-8 May 2015; pp. 92-94.

47. Stovall, J.; Crandall, K. Quadrupole Law and Steering Options in the Linac4 DTL; sLHC-Project-Note-0006; European Organization for Nuclear Research: Geneva, Switzerland, 2009.

48. Gerigk, F. Status and Future Strategy for Advanced High Power Microwave Sources for Accelerators. In Proceedings of the IPAC2018, Vancouver, BC, Canada, 29 April-4 May 2018; pp. 12-17.

49. Thales. Available online: https://www.thalesgroup.lcom (accessed on 1 August 2021).

50. Sun, L.; Shi, A.; Zhang, Z.; Shi, L.; Xu, X.; Li, C.; Wang, W.; Lu, L. Overview of RF System for C-ADS Injector II Radio Frequency Quadrupole. High Power Laser Part. Beams 2017, 29, 065107.

51. Chun, M.H.; Park, K.H.; Yu, I.H.; Lee, Y.S.; Kim, D.S.; Seo, M.H.; Moon, Y.J.; Ok, J.W.; Won, M.S.; Hong, J.; et al. Design Study on a High Power RF Amplifier for the RFQ. In Proceedings of the IPAC'15, Richmond, VA, USA, 3-8 May 2015; pp. 3009-3011.

52. Mendez, P.; Regidor, D.; Weber, M.; de la Morena, C.; Kirpitchev, I.; Garcia, A.; Marqueta, A.; Pereira, A.; Molla, J.; Ibarra, A.; et al. LIPAc RF Power System: Design and Main Practical Implementation Issues. Fusion Eng. Des. 2021, 165, 112226. [CrossRef]

53. Lyles, J.; Archuletta, S.; Davis, J.; Rees, D.; Torrez, P.; Baca, D. Progress on New High Power RF System for LANSCE DTL. In Proceedings of the PAC07, Albuquerque, NM, USA, 25-29 June 2007; pp. 2382-2384.

54. Lyles, J.; Barkley, W.; Davis, J.; Rees, D.; Sandoval, G. Installation and Operation of Replacement 201 MHz High Power RF System at LANSCE. In Proceedings of the IPAC'15, Richmond, VA, USA, 3-8 May 2015; pp. 3485-3488.

55. CPI-Eimac. Available online: https://www.cpii.com (accessed on 1 August 2021).

56. Canon. Available online: https://etd.canon/en/product/category/microwave/klystron.html (accessed on 1 August 2021).

57. Langlois, M. SSA Using a Cavity Combiner, Elettra Synchrotron, Trieste, Italy. Available online: https://indico.cern.ch/event/27 6274/contributions /625698/attachments/501447/692514/ML_CWRF.pdf (accessed on 1 August 2021).

58. De la Morena, C.; Regidor, D.; Iriarte, D.; Sierra, F.; Ugarte, E.; Dragaš, S.; Marini, P.; Molla, J.; Ibarra, A. First Validation Experiments of the Prototype Solid State RF System for IFMIF-DONES. Fusion Eng. Des. 2021, 168, 112396. [CrossRef]

59. Gasper, M.; Garvey, T. Solid State Amplifier Development for the Swiss Light Source. In Proceedings of the IPAC'15, Richmond, VA, USA, 3-8 May 2015; pp. 3170-3172. 